\title{
Detection and Identification of Tomato Yellow Leaf Curl Virus-EG Using Molecular Technique
}

\author{
Kh. A. El-Dougdoug, Ibtisam A. Hammad", Hayam S. Abd \\ El-Kader**, Entsar A. Ahmed" and Asmaa F. Abd El- \\ Monem* \\ Microbiology Department, Faculty of Agriculture, Ain Shams \\ University; "Botany \& Microbiology Department, Faculty of \\ Science, Helwan University and ${ }^{* * *}$ Virus and Phytoplasma \\ Research Department, Plant Pathology Research Institute, \\ Agriculture Research Centre (ARC), Cairo, Egypt.
}

\begin{abstract}
7 OMATO Yellow Leaf Curl virus (TYLCV-Eg) was isolated from whiteflies-infected tomato (Lycopersicon esculentum $c v$. Castle rock) plants growing in Nubaria and El-Behera Governorate. The infected plants exhibited systemic viral symptoms in the form of severe leaf curling, leaf crinkle with marginal yellowing, stem upright, twisted and stunted. TYLCV-Eg reacted positively with polyclonal antibodies specific to TYLCV using DAS-ELISA. It was transmitted by both syringe injection and whiteflies with transmission efficiency of about $80 \%$ and $100 \%$, respectively. TYLCV-Eg isolate was transmitted to different species belonging to families Cucurbitaceae, Fabaceae, Solanaceae and Chenopodiaceae. TYLCV had TIP (Thermal Inactivation Point) of $70^{\circ} \mathrm{C}$, DEP (Dilution End Point) of $10^{-7}$ and LIV (Longevity) of about 6 days. Electron micrograph of the partially purified TYLCV revealed the presence of monomer and dimmer gemini particles with dimensions of $22 \mathrm{~nm}$ and $20 \times 30 \mathrm{~nm}$ to $24 \times 30 \mathrm{~nm}$, respectively when negatively stained with uranyl acetate. DNA from infected plants was extracted and amplified successfully by polymerase chain reaction (PCR) using degenerate oligonucleotide primers V324(+) and C889 (-) producing 500 bp fragment from infected tomato plants. The viral genome was detected by specific DNA probe using dot blot hybridization technique. Comparative nucleotide sequence analysis showed a similarity of $98 \%$ between TYLCV-EG and other isolates.
\end{abstract}

Keywords: Nucleotide sequence, TYLCV-EG, DAS-ELISA, PCR, Dot-blot hybridization,

Tomato Yellow Leaf Curl virus (TYLCV) belongs to genus begomovirus of family Geminiviridae. TYLCV is a severe viral disease of tomato ( $L$. esculentum) in Egypt. Tomato plantings in the Middle East countries have been severely affected since 1960 (Czosnek \& Laterrot, 1997). TYLCV disease has emerged in countries around the river and Mediterranean Basins in the last 20 years (Fauquet et al., 2005). Moustafa (1991) recorded that $100 \%$ of the fallgrown tomato plants are usually infected with TYLCV and production losses reached $80 \%$.

For correspondence: hayamabdelkader @yahoo.com. Present addres: Biotechnology Dept.,Taif Univ., KSA 
The symptoms of disease become visible in tomato 2-3 weeks after infection and consist of upward curling of leaflet margins, yellowing of young leaves and abortion of flowers. Those leaflets that appear soon after inoculation are cupped down and inwards. Infected plants are severely stunted and resulting in decrease of plant growth and reduced total yield (Sinisterra et al., 2000; Sider et al., 2001; Gafni, 2003 and Crescenzi et al., 2004).

The morphology of geminivirus particles is unique and they are characterized by twin icosaheaderal capsid approximately $20 \times 30 \mathrm{~nm}$ in size encapsidating a single molecule of covalently closed circular single stranded DNA (ssDNA) genomes of 2500 to $3000 \mathrm{bp}$ that replicate in the nuclei of the infected cells via a double stranded DNA (dsDNA) intermediate (Harrison \& Robinson, 1999 and Varma \& Malathi, 2003).

Polymerase chain reaction (PCR) using specific or degenerate primers have proved to be a rapid, accurate and efficient method of detecting and determining genetic diversity among geminiviruses (Aref et al., 1994). Sequencing of PCR fragments has contributed to the classification and phylogeny of geminiviruses (Rojas, 1992). The DNA genome of geminiviruses can be easily detected by nucleic acid hybridization visualizing geminiviral DNA-labelled digoxigenin probes (Gilbertson et al., 1991). This paper describes the biological and molecular identification of TYLCV-EG isolate.

\section{Materials and Methods}

Source of the virus isolate

Ninety samples of naturally infected tomato (Lycopersicon esculentum cv.Castle rock) plants showing symptoms suspected to TYLCV were collected from El-Behera Governorate. The collected samples were examined for the presence of TYLCV serologically by DAS-ELISA (Clark \& Adams, 1977).

\section{Isolation and propagation of TYLCV}

The infected plants which gave positive results with DAS-ELISA were used as a source of the TYLCV under study. The virus isolate was inoculated on healthy tomato cv. Super marmand plants using virus free whiteflies, Bemisia tabaci biotype B. Insect inoculated plants were kept in insect-proof cages under greenhouse conditions at the faculty of Agriculture, Ain Shams University for 3 6 weeks. The new symptoms appeared similar to the original symptoms were examined by dot blot hybridization to confirm the existence of the original virus isolate.

\section{Biological characters}

Syringe injection

Healthy tomato plants cv. super marmand were inoculated by syringes using infected tomato sap as described previously (Allam et al., 1994). The inoculated plants as well as uninoculated ones were kept under greenhouse conditions and

Egypt. J.Microbiol. 45 (2010) 
symptoms were observed daily up to 60 days. Syringe transmission efficiency was recorded as a number of infected plants / total number of exposed plants.

\section{Insect transmission}

Whiteflies Bemisia tabaci biotype B belongs to family Aleroididae were collected from tomato plants grown in open fields and identified by the Department of Plant Protection, Faculty of Agriculture, Ain Shams University. Virus-free whiteflies were used as vectors in transmission experiment and Insect transmission was done as previously described by Ghanem et al., (2001). The collected insects were caged with healthy Ipomoea batatas (sweet potato) plants and left for two days.The adult insects were killed using selecron as systemic insecticides. These plants were kept in glass cages until the larvae developed. The adults were then transferred to healthy I. batatas. After consecutive transfers, the resulting virus-free insects were used as vectors in transmission experiment. About twenty insects allowed to feed on infected tomato cv. super marmand plants in insect proof cages. After $24 \mathrm{hr}$ acquisition access period, the insect allow to feed for $72 \mathrm{hr}$ on healthy tomato plants then the whiteflies were removed by spraying the tomato plants by $0.5 \%$ selecron and left for symptoms development. Insect inoculated plants were observed daily for a period of about 60 days. Insect transmission efficiency was recorded as number of infected plants / total number of inoculated plants.

\section{Host range and symptomatology}

Nineteen species and varieties belonging to six families (Solanaceae, Cucurbitaceae, Leguminosae, Chenopodiaceae, Compositae and Graminae) were inoculated with the studied virus isolate under greenhouse conditions. External symptoms were observed for 60 days and confirmed by ELISA and dot blot hybridization assay.

\section{Stability of virus isolate}

Thermal Inactivation Point (tested at certain temperatures, started with $40^{\circ} \mathrm{C}$ with $5^{\circ} \mathrm{C}$ intervals to $90^{\circ} \mathrm{C}$ in water bath for $10 \mathrm{~min}$ ), Dilution End point (starting from $10^{-1}$ to $10^{-10}$ ) and aging (at room temperature of $25^{\circ} \mathrm{C}-28^{\circ} \mathrm{C}$ for 10 days) of TYLCV was performed on healthy L. esculentum cv. super marmand by using infectious crude sap obtained from infected tomato plants macerated in phosphate buffer $\mathrm{pH} 7.2(1: 1 \mathrm{w} / \mathrm{v})$. The injected seedlings were kept under greenhouse conditions and observed daily up to 60 days for symptoms development. Stability of TYLCV was recorded as number of infected plants/ total number of inoculated plants.

\section{Morphological characters}

Partially purified suspension of TYLCV was prepared according to Black et al. (1963) and examined by electron microscope at the Electron Microscope Unit, National Research Centre, Dokki, using negative staining (2\% Uranyle acetate $\mathrm{pH}$ 7.0) technique as described by Noordam (1973). 


\section{Molecular characters}

\section{Extraction of viral DNA}

Genomic DNA was extracted from TYLCV infected L. esculentum plants using cetyl trimethyl ammonium bromide method (CTAB) as described by Gibbs \& Mackenize (1997). Samples were prepared by grinding 50 -100 mg fresh leaf tissue homogenenized in liquid nitrogen to a fine powder and $500 \mu \mathrm{l}$ of wash buffer was added to the powdered leaves before adding CTAB buffer. The mixture was centrifuged for 5-10min. Supernatant was removed and $600 \mu 1$ of CTAB buffer was added. The mixture was mixed and incubated at $60^{\circ} \mathrm{C}$ for 20 min with gentle agitation. After the solution has cooled down, 1volume chloroform:3 isoamylalcohol were added. The tubes were centrifuged at $3,000 \mathrm{rpm}$ for $25 \mathrm{~min}$ at $10^{\circ} \mathrm{C}$. The upper aqueous phase was transferred to a fresh tube and re-extracted with $2 \mathrm{ml}$ of $10 \%$ $\mathrm{CTAB}$ and the mixture was incubated at $65^{\circ} \mathrm{C}$. Chloroform:isoamylalcohol extraction was repeated and the mixture was centrifuged at $3,000 \mathrm{rpm}$ at $10{ }^{\circ} \mathrm{C}$ for $25 \mathrm{~min}$. $2 / 3$ volume isopropanol was added to the upper supernatant phase in a fresh tube. The DNA collected by centrifugation at 10,000 rpm for $20 \mathrm{~min}$. The liquid was drained carefully and the DNA pellets were washed with $70 \%$ ethanol and the tubes were centrifuged at 5,000 rpm for $5 \mathrm{~min}$. DNA pellets were dried and re-suspended in $200 \mu \mathrm{l} \mathrm{TE}$ buffer. Four $\mu \mathrm{l}$ RNase A $(10 \mathrm{mg} / \mathrm{ml})$ was added and incubated at $65^{\circ} \mathrm{C}$ for $1 \mathrm{hr}$. The DNA was precipitated again by adding 0.1 volume $3 \mathrm{M}$ sodium acetate and 0.7 volume isopropanol and left overnight at $4^{\circ} \mathrm{C}$. The tubes were centrifuged at maximum speed for $15 \mathrm{~min}$ at $4^{\circ} \mathrm{C}$ and the DNA pellets were washed with $500 \mu \mathrm{l}$ $70 \%$ ethanol, centrifuged for $5 \mathrm{~min}$ then air dried and resuspended in $20 \mu \mathrm{l}$ of dd $\mathrm{H}_{2} \mathrm{O}$. The nucleic acid was stored at $-20^{\circ} \mathrm{C}$.

\section{Oligonucleotide primers}

The oligonucleotide primers used to amplify the coat protein gene of TYLCV was commercially obtained from Operon, (Qiagen Company, 1000 Atlantic Avenue, Suite 108. A lameda, CA., 94501). Oligonucleotide degenerate primers were selected according to Brown et al. (2001). V324 (+) primer corresponding to 5' GCC YAT RTA YAG RAA GCC MAG 3' and C889 (-) primer corresponding to 5' GGR TTD GAR GCA TGH GTA CAT G 3'.

\section{PCR amplification}

PCR reaction mixture of $2.5 \mu \mathrm{l}(200 \mathrm{ng})$ of extracted DNA, $10 \mathrm{mM}$ of each dNTPs $(0.5 \mu \mathrm{l}), 1 \mu \mathrm{l}$ of 25 pmole from each amplification primer, $2.5 \mu \mathrm{l}$ of $10 \mathrm{X}$ PCR buffer with $1.5 \mathrm{mM} \mathrm{MgCl}_{2}$ and $0.5 \mu \mathrm{l}$ Taq DNA polymerase (Roche). The amplification reaction was carried out in a total volume of $25 \mu \mathrm{l}$ using PCR thermal cycler, UNOII from Biometra and using $0.2 \mathrm{ml}$ micro Amp PCR tubes with denaturation at $94^{\circ} \mathrm{C}$ for $30 \mathrm{sec}$, annealing at $50^{\circ} \mathrm{C}$ for $45 \mathrm{sec}$, and extension at $72^{\circ} \mathrm{C}$ for $1 \mathrm{~min}$. A single tailing cycle of long extension at $72^{\circ} \mathrm{C}$ for 7 min was carried out in order to ensure flush ends on the DNA molecules. Finally, the amplification reactions were hold at $4^{\circ} \mathrm{C}$. The amplified DNA was electrophoreses on $1 \%$ agarose gel and photographed using gel documentation system from UVP-CCD Camera, Laboratory products, Epichemi, 11 Darkroom, 3 UV Transilluminator, Pharmacia.

Egypt. J.Microbiol. 45 (2010) 
Dot blot hybridization assay

Digoxigenin-11-dUTP-labeled DNA probe, corresponding to TYLCV/CPs were prepared by using 10X DNA labeling nucleotide mix (Roche, Boehringer Mannheim, Indianapolis). Digogxigenin-11-dUTP nucleotide mix was incorporated into the PCR cocktail instead of the normal nucleotide mix using the protocol described under the technical bulletin (Roche, Boehringer Mannheim, Indianapolis).

Non-radioactive DNA hybridization was used to TYLCV-DNA in infected plant tissues with typical symptoms of TYLCV and/or without symptoms. The nucleic acid of infected samples was extracted as described by Loebenstein $e t$ al. (1997) and $5 \mu \mathrm{l}$ of each extract was spotted directly on the nitrocellulose membrane. The DNA was fixed on the membranes by ultraviolet (U.V) cross linked for 3 min.

Membrane was subjected to prehybridization, hybridization, and colorimetric detection procedures according to the protocol described by "Genius II DNA labeling and detection kit" (Boehringer Mannheim IN).

\section{Automated DNA sequencing}

The resulting PCR product of TYLCV was purified by using GFX column and Gel Band purification kit (Amersham pharmaia Biotech, GmbH, Germany). The TYLCV coat protein genes ( $\sim 360 \mathrm{bp})$ were sequenced on one direction using V324 (+) primer. The sequence was carried out using ABI PRISM model 310, version 5.3.1 at gene analysis unit, VACSERA, Cairo, Egypt. Nucleotide sequence analyses were performed using the published nucleotide sequences of TYLCV coat protein genes from Gene Bank.

\section{Results and Discussion}

\section{Field inspection and serological detection}

Whiteflies-infected tomato plants with TYLCV showed viral symptoms of sever leaf curling, leaf crinkle with marginal yellowing, stem upright, twisted and stunted. All samples gave positive reaction and were susceptible to tomato yellow leaf curl viral infection with different degrees of disease severity. These results indicated that the incidence of TYLCV in governorate was $100 \%$, (Table 1). These result reported by many investigators (El-Dougdoug et al., 1996; Czosnek \& Laterrot, 1997; Sinisterra et al., 2000; Sider et al., 2001; Polston et al., 2002; Gafni, 2003; Crescenzi et al., 2004; Ajlan et al., 2006 and Zambrano et al., 2007). All samples collected from Nubaria, El-Behera Governorate gave positive reaction and the incidence of TYLCV was $100 \%$. This result indicated that the presence of high population of whiteflies that transmitted TYLCV efficiently resulted in increasing TYLCV infection in open fields. 
TABLE 1. Detection of TYLCV in different samples of naturally infected tomato cv. Castle rock plants by DAS-ELISA using specific polyclonal antibody.

\begin{tabular}{|c|c|c|}
\hline Location & Symptoms & $\begin{array}{c}\text { ELISA- } \\
\text { reading } \\
(\text { O.D) }\end{array}$ \\
\hline 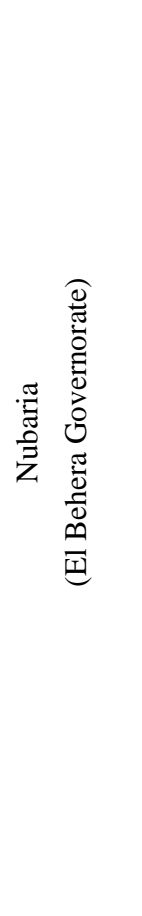 & $\begin{array}{c}\text { LC,MY, SU, S } \\
\text { LC, MY } \\
\text { LC, MY,ST, S } \\
\text { LC, MY } \\
\text { LK } \\
\text { LC, MY } \\
\text { LC, MY } \\
\text { LC, MY } \\
\text { LC, MY } \\
\text { LK, MY } \\
\text { LC, MY } \\
\text { LC, MY } \\
\text { LC, MY, ST, S } \\
\text { LC, MY } \\
\text { LK, MY } \\
\text { LC, MY } \\
\text { LC, MY } \\
\text { LC, MY } \\
\text { LC, MY }\end{array}$ & $\begin{array}{l}2.08 \\
1.953 \\
2.317 \\
1.468 \\
0.142 \\
0.149 \\
0.226 \\
0.133 \\
0.123 \\
0.123 \\
0.133 \\
0.185 \\
2.423 \\
0.135 \\
0.105 \\
0.109 \\
0.122 \\
0.164 \\
2.375\end{array}$ \\
\hline
\end{tabular}

O.D = optical density, LC=leaf curling, LK=leaf crinkle, MY=marginal yellowing, $\mathrm{SU}=$ stem upright, $\mathrm{ST}=$ stem twisting, $\mathrm{S}=$ stunting. Negative control=0.011, positive control $=3.18$.

Isolation and propagation of virus isolates

TYLCV was isolated and propagated on healthy tomato plants cv.super marmand from the selected ELISA positive tomato samples by whitefly ( $B$. tabaci biotype B) transmission. After 3-5 weeks post infection, typical external symptoms of leaf curling, leaf crinkle with marginal yellowing produced till it gives deformation and stunted plant growth after 5-6 weeks from insect inoculation (Fig. 1). This result was agreement with other investigation (Abouzid et al., 2002). High ELISA readings indicated high virus concentration in naturally infected tomato plants. 


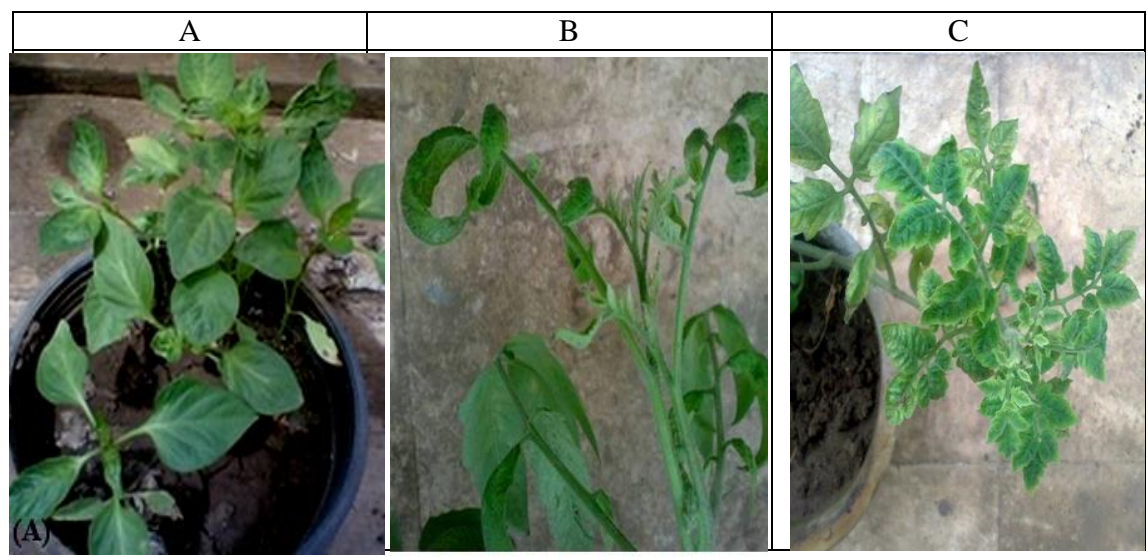

Fig. 1. Symptoms of TYLCV on L. esculentum cv. Super marmand whitefly inoculated showing Leaf curling, leaf crinkle (A), Cup shape leaves (B). Leaf curling, yellowing and stem upright and stunted plant growth $(C)$.

Biological characters of virus isolate

Mode of transmission

Results in Table 2 showed that both syringe and whitefly inoculation methods transmitted TYLCV from infected tomato plants cv. super marmand to healthy ones but the efficiency of whitefly transmission was higher than the efficiency of syringe injection.

TABLE 2. Mode of transmission of TYLCV.

\begin{tabular}{|c|c|c|c|c|c|}
\hline $\begin{array}{l}\text { Virus } \\
\text { isolate }\end{array}$ & $\begin{array}{c}\text { Transmission } \\
\text { mode }\end{array}$ & Symptoms & $\begin{array}{c}\text { Incubation } \\
\text { period } \\
\text { (weeks) }\end{array}$ & $\mathbf{A} / \mathbf{B}$ & $\begin{array}{c}\% \text { Virus } \\
\text { transmission } \\
\text { efficiency }\end{array}$ \\
\hline \multirow{4}{*}{ TYLCV } & \multirow{2}{*}{$\begin{array}{l}\text { Syringe } \\
\text { Injection }\end{array}$} & $\begin{array}{l}\text { Leaf curling and } \\
\text { leaf crinkle }\end{array}$ & $2-4$ & \multirow[t]{2}{*}{$16 / 20$} & \multirow[t]{2}{*}{$80 \%$} \\
\hline & & $\begin{array}{c}\text { Marginal } \\
\text { yellowing and } \\
\text { stunting } \\
\end{array}$ & 4 & & \\
\hline & \multirow[b]{2}{*}{$\begin{array}{c}\text { Whitefly ( } B . \\
\text { tabaci } \\
\text { biotype B) }\end{array}$} & Leaf curling & $3-5$ & \multirow[b]{2}{*}{$20 / 20$} & \multirow[b]{2}{*}{$100 \%$} \\
\hline & & $\begin{array}{l}\text { Marginal } \\
\text { yellowing, stem } \\
\text { twisting and } \\
\text { stunting }\end{array}$ & 5 & & \\
\hline
\end{tabular}

$\mathrm{A} / \mathrm{B}=$ Number of infected plants / total number of inoculated plants.

In case of syringe injection, symptoms of leaf crinkle and leaf curling were first developed after 2-4 weeks till it gives marginal yellowing and stunting of tomato plants after 4 weeks while in case of whitefly (B. tabaci biotype B) transmission, leaf curling with marginal yellowing were first developed after 3-5 
weeks till it gives cup shape leaves, stem twisted and sever stunting after 5 weeks at $28-30^{\circ} \mathrm{C}$ under greenhouse. These results are in agreement with that obtained by Abdel Salam (1991b), Allam et al. (1994) and El-Dougdoug \& Aref (1996) while, Ioannou (1985) and Credi et al. (1989) reported that first TYLCV symptoms on tomato plants appear 2-4 weeks after inoculation and become fully developed after a period of up to 2 months.

\section{Host range and symptomology}

Results showed that TYLCV isolate infected large number of species from family Solanaceae. In addition, TYLCV infected a few species of family Cucurbitaceae, Fabaceae and Chenopodiaceae. On the other hand, no symptoms were observed on Compositae and Graminae. Table 3 illustrated the different symptoms produced on the different plant species when inoculated with TYLCV by both syringe injection and whitefly (B. tabaci biotype B) transmission. These results are in agreement with that obtained by Abdel Salam (1991b), Allam et al. (1994) and El-Dougdoug \& Aref (1996) while, Ioannou (1985) and Credi et al. (1989) reported that first TYLCV symptoms on tomato plants appear 2-4 weeks after inoculation and become fully developed after a period of up to 2 months.

\section{Morphology of virus particles}

Electron microscopic examination of partially purified preparation of TYLCV revealed the presence of isometric and pentagonal in shape, with single and paired Gemini virus, (monomers and dimmers) with dimension of $22 \mathrm{~nm}$ and $20 \times 30 \mathrm{~nm}$ to $24 \times 30 \mathrm{~nm}$, respectively when negatively stained with $2 \%$ Uranyl acetate $\mathrm{pH}$ 7.0, (Fig. 2). These results were similar with that reported in other studies (Abdel-Salam, 1991a; Lazarwaitz, 1992; Argüello-Astorga et al., 1994; El-Dougdoug et al., 1996; Harrison \& Robinson, 1999; Varma \& Malathi, 2003 and Ajlan et al., 2006).

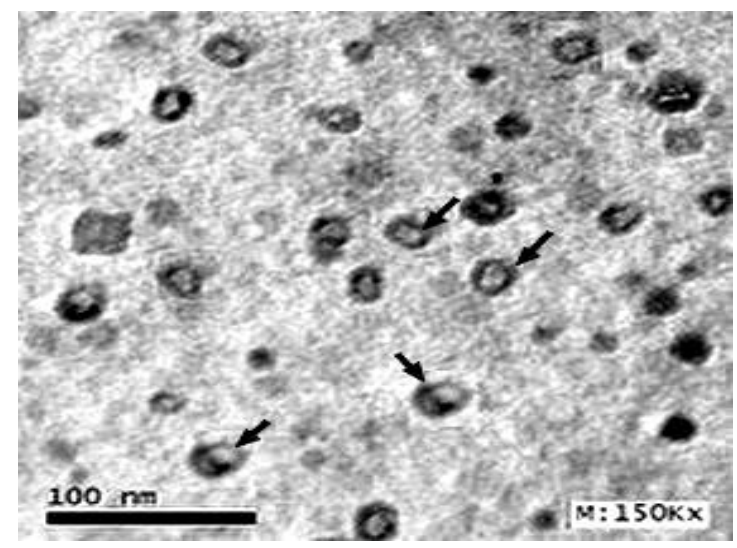

Fig. 2. Electron micrographs showing the partially purified squash leaf curl gemiviruse negatively stained with $2 \%$ Uranyl acetate, Bar represents $100 \mathrm{~nm}$. 
DETECTION AND IDENTIFICATION OF TOMATO YELLOW...

TABLE 3. Host range of TYLCV as determined by syringe injection and whitefly $(B$. tabaci) transmission. Presence of virus was confirmed by DAS-ELISA and DNA hybridization.

\begin{tabular}{|c|c|c|c|c|c|c|}
\hline \multirow[b]{2}{*}{ Host plants } & \multicolumn{3}{|c|}{ Syringe injection } & \multicolumn{3}{|c|}{ Whitefly inoculation } \\
\hline & Symptoms & O.D. & D.B.H. & Symptoms & O.D. & D.B.H. \\
\hline Solanaceae & & & & & & \\
\hline L. esculentum & LK,LC,M & 3.950 & ++ & LK ,LC, MY, & 1.940 & ++ \\
\hline cv. super marmand & Y, SU,S & & & SU, S & & \\
\hline C. annum cv. Chilli & LK,M & 0.582 & + & $\mathrm{Lk}, \mathrm{M}, \mathrm{S}$ & 0.548 & + \\
\hline D. stramonium & LK,E, M,S & 2.083 & ++ & LK,E,M,S & 1.966 & ++ \\
\hline D. metel & Mild LK & 0.682 & + & Mild LK & 0.500 & + \\
\hline N. glutinosa & $\mathrm{LC}, \mathrm{R}, \mathrm{B}, \mathrm{M}$ & 1.885 & ++ & B & 0.796 & ++ \\
\hline N. rustica & $\mathrm{S}$ & 0.204 & $-\mathrm{ve}$ & (0) & 0.222 & $-\mathrm{ve}$ \\
\hline N. tabacum & (0) & $(\mathrm{Na})$ & $(\mathrm{Na})$ & (0) & $(\mathrm{Na})$ & $(\mathrm{Na})$ \\
\hline cv. whiteBurley & $\mathrm{VC}$ & 0.510 & + & VC & 0.644 & + \\
\hline Samson & $\mathrm{VC}$ & 0.488 & + & $\mathrm{VC}$ & 0.500 & + \\
\hline Cucurbitaceae & & & & & & \\
\hline C. pepo cv. Eskandrani. & Mild LK & 1.200 & + & Mild LK & 0.506 & + \\
\hline C. maxima & (0) & 0.274 & $-\mathrm{ve}$ & (0) & 0.157 & -ve \\
\hline C. sativus & (0) & 0.210 & -ve & $(0)$ & 0.232 & -ve \\
\hline Fabaceae & & & & & & \\
\hline P. vulgaris & $\mathrm{LK}, \mathrm{M}$ & 0.844 & ++ & $\mathrm{LK}, \mathrm{N}, \mathrm{M}$ & 0.570 & ++ \\
\hline G. $\max$ & $\mathrm{LC}, \mathrm{R}, \mathrm{NM}$, & 2.516 & ++ & LC,R & 1.500 & ++ \\
\hline P.sativum & VC & 0.242 & -ve & $(0)$ & 0.234 & -ve \\
\hline$V \cdot f a b a$ & $\begin{array}{l}(0) \\
(0)\end{array}$ & $\begin{array}{c}0.224 \\
(\mathrm{Na})\end{array}$ & $\begin{array}{l}-\mathrm{ve} \\
(\mathrm{Na})\end{array}$ & $\begin{array}{l}(0) \\
(0)\end{array}$ & $\begin{array}{c}0.250 \\
(\mathrm{Na})\end{array}$ & $\begin{array}{l}-\mathrm{ve} \\
(\mathrm{Na})\end{array}$ \\
\hline Chenopodiaceae & & & & & & \\
\hline Ch. amaranticcolor & (0) & 0.252 & -ve & -ve & 0.250 & -ve \\
\hline B. vulgaris & $\mathrm{LC}, \mathrm{E}$ & 0.538 & + & $\mathrm{LC}$ & 0.490 & + \\
\hline Graminea & & & & & & \\
\hline $\begin{array}{l}\text { Z. mays } \\
\text { Compositae }\end{array}$ & (0) & 0.238 & -ve & -ve & 0.790 & -ve \\
\hline L. sativa & (0) & 0.254 & -ve & -ve & 0.200 & -ve \\
\hline
\end{tabular}

O.D.=optical density, D.B.H=dot blot hybridization, LK=leaf crinkle , LC=leaf curling, MY=marginal yellowing, $S U$ stem upright, $S=$ stunting, $E=e$ epinosity, $M=$ malformation, $\mathrm{R}=$ rugosity, $\mathrm{B}=$ blistering, $\mathrm{VC}=$ vein clearing, $\mathrm{NM}=$ net mosaic, $\mathrm{N}=$ necrosis. Negative control of sap inoculation $=0.149$, negative control of whitefly transmission $=0.139,++=$ strong positive reaction, $+=$ weak positive reaction, $-\mathrm{ve}=$ negative reaction, $(0)$ symptomless, and $(\mathrm{Na})=$ not applicable . 
Molecular characterization of virus isolate

TYLCV DNA prepared from infected tomato plants were amplified by PCR using the oligonucleotides V324 (+) and C889 (-) as PCR primers as reported by Brown et al. (2001). The size of the PCR product of coat protein gene (CP) amplified from infected tomato plants was estimated by comparing its electrophoretic mobility with those of standard DNA ladder as shown in Fig. 3. The amplified DNAs were in the expected size calculated ( 500 bp) from the positions of the primers. The authenticity of the resulting PCR products was verified by direct DNA sequencing after purification of the DNA fragments from agarose gel using rapid and efficient gel purification kit from Amersham Pharmaia Biotech, GmbH, Germany.

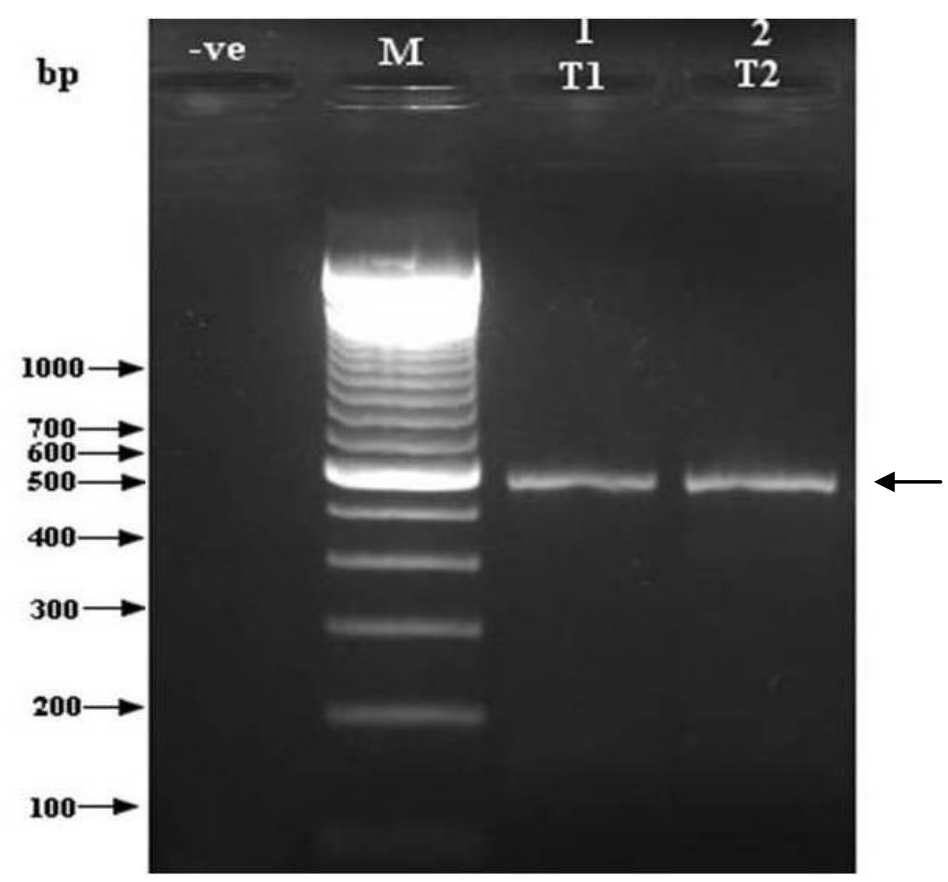

Fig. 3. 1.5\% agarose gel electrophoresis showing the PCR products of TYLCV coat protein gene using Begomoviruses specific primers V324 (+) \& C889 (-). Genomic DNAs were extracted from naturally infected tomato leaves (T1) and syringe injected tomato plants (T2). The arrow pointed to the amplified PCR products ( 500 bp) (Lanes 1 to 2$)$. M: Molecular weight DNA ladder (100 bp ladder, BRL). -ve: Negative control (No DNA template).

Dot blot hybridization assay

Membrane hybridization result of TYLCV infected plants showed that $L$. esculentum, D.stramonium, N. glutinosa, P. vulgaris and G.max gave a strong positive reaction while $C$. annum, D.metel, $N$. tobacum cv.whiteberly, $N$. tobacum cv.samson, $C$. pepo and B.vulgaris gave a mild positive reaction. On the 
other hand, N. rustica, C. maxima, C. sativus, P. sativum, V. faba, Ch. amaranticolor, Z. mays and L. sativa gave negative reaction (Fig.4).

A

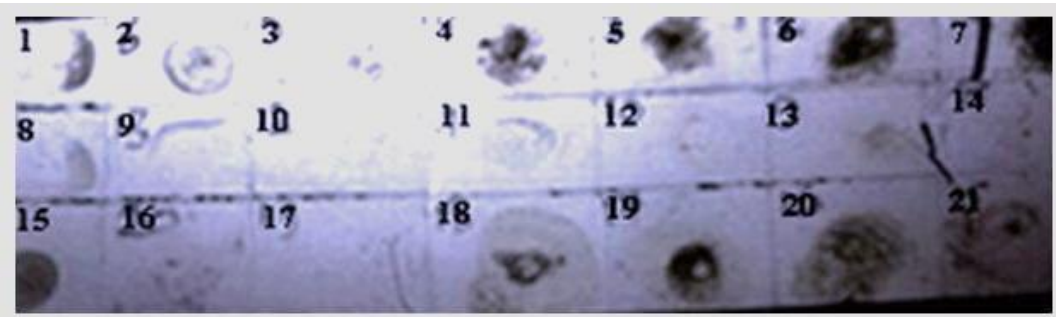

B

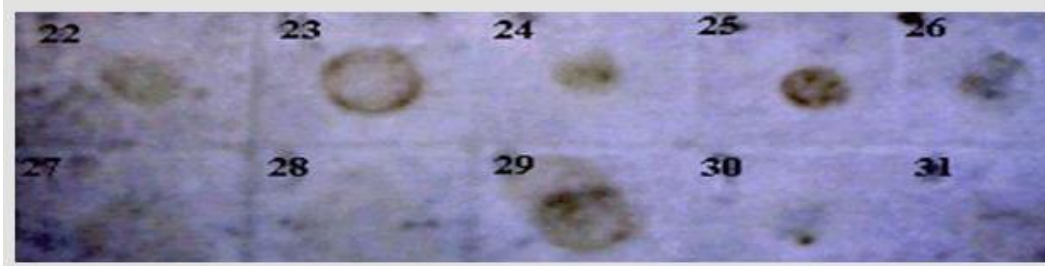

$\mathrm{C}$

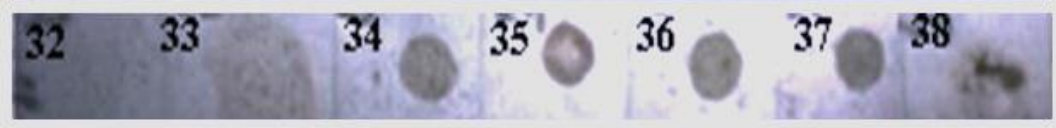

Fig. 4. Dot blot hybridization of syringe and whitefly inoculated plants using TYLCV- DNA probe.

Sequence analysis of TYLCV/CP genes

A multiple sequence alignment of TYLCV/Cp nucleotide sequence (current study) with four TYLCV sequences published in the GenBank. Sequence comparison showed that TYLCV/Cp of the current study had sequence homology of about $98 \%$ with other TYLCV isolates (Fig. 5 A\&B). TYLCV-CP was found to display $95.6 \%$ sequence homology with EF107520 (TYLCV-Nob) reported by Abdallah et al. (2000), $92.4 \%$ with AY594174 (TYLCV- Egyptian isolate) reported by Abhary et al. (2006), $88.7 \%$ with FJ030876 (TYLCV - H11) reported by Abdel-Salam \& Rehman (2008), $90.0 \%$ with EU635776 (TYLCV Iranian isolate) reported by Fazeli et al. (2009). Multiple sequencing alignments were generated using (DNAMAN V 5.2.9 package, Madison, Wisconsin, USA). The homology tree of TYLCV-EG presented in Fig. 5B revealed high degree of similarity ( $98 \%)$ to the other four isolates sequences of TYLCV.

To study the molecular characters of the isolated virus, purified TYLCV DNA was used in PCR using degenerate oligonucleotide primers V324 (+) and C889 (-) as reported by Brown et al. (2001). The size of the PCR product of coat protein gene $(\mathrm{CP})$ amplified from naturally infected tomato plants was $\sim 500 \mathrm{bp}$.

Non-radioactive DNA hybridization method using Digoxigenin-11-dUTPlabeled DNA probe, corresponding to TYLCV/CPs was used to detect TYLCV from infected samples. The Dig-labelled probe was capable of detecting TYLCV-DNA with different degrees of sensitivity. 

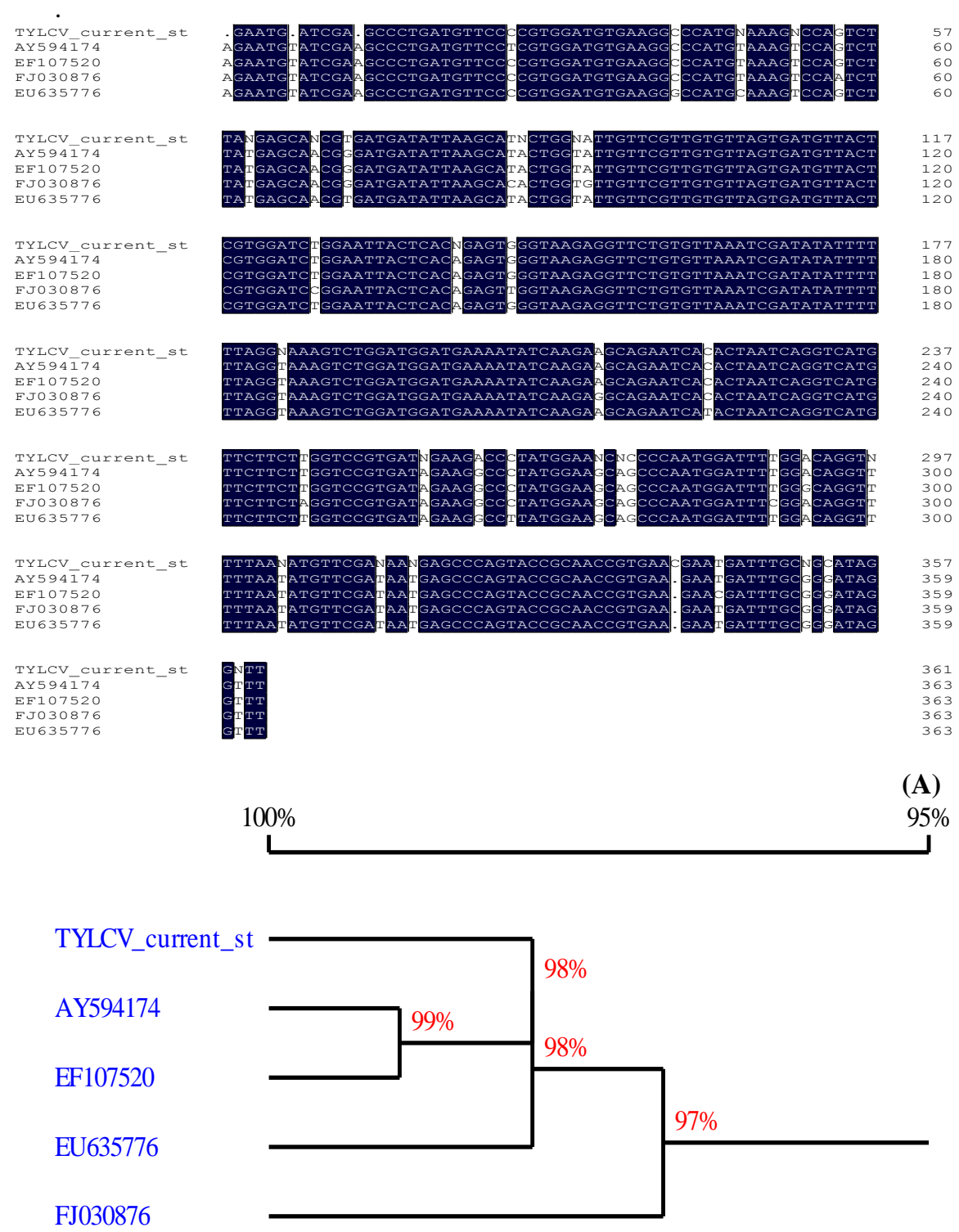

(B)

Fig. 5. ( A\&B). Multiple sequence alignment and homology tree of TYLCV isolates based on the nucleotide sequences of the $\mathrm{CP}$ gene. Accession numbers indicated above were as following: TYLCV-current study, AY594174 (TYLCV- Egyptian isolate) reported by Abhary et al. (2006). EF107520 (TYLCV-Nob) reported by Abdallah et al. (2000), EU635776 (TYLCV Iranian isolate) reported by Fazeli et al. (2009), FJ030876 (TYLCV - H11) reported by Abdel-Salam \& Rehman (2008).

Egypt. J.Microbiol. 45 (2010) 
Partial nucleotide sequence ( 360 nt) of TYLCV-CP-EG of the current study was aligned with other published CP sequences of TYLCV as shown in Fig. 5A. TYLCV-CP was found to display $95.6 \%$ sequence homology with EF107520 (TYLCV-Nob) reported by Abdallah et al. (2000), $92.4 \%$ with AY594174 (TYLCV- Egyptian isolate) reported by Abhary et al. (2006), $88.7 \%$ with FJ030876 (TYLCV - H11) reported by Abdel-Salam \& Rehman (2008), $90.0 \%$ with EU635776 (TYLCV Iranian isolate) reported by Fazeli et al (2009). Multiple sequencing alignments were generated using (DNAMAN V 5.2.9 package, Madison, Wisconsin, USA). The homology tree of TYLCV-EG presented in Fig. 5B revealed high degree of similarity ( 98\%) to the other four isolates sequences of TYLCV.

The obtained results of biological and molecular study of TYLCV-EG (current isolate) showed some different characters from the other begomovirus strains reported. Further research should be done to identify the species of begomoviruses infecting the Egyptian tomatoes. Identification through sequencing is necessary in order to map the diversity and evolution of begomoviruses and to understand the appearing of reemerging new isolates.

\section{References}

Abdallah, N.A., Fauquet, C.M., Beachy R.N. and Madkour, M.A. (2000) Cloning and constructing infectious clones of an Egyptian isolate of Tomato Yellow Leaf Curl Virus. Arab J. Biotechnol. 3 (1), 35-54.

Abdel-Salam, A.M. (1991a) Tomato Yellow Leaf Curl Virus in Egypt:1-Characterization, partial purification and anti-serum production. Bull. Fac. Agric., Univ. Cairo, 42, 507-520.

Abdel-Salam, A.M. (1991b) Tomato Yellow Leaf Curl Virus in Egypt: 2-The use of its locally induced antiserum for the detection of its incidence in economic and wild plants in the field. Bull. Fac. Agric., Cairo, Univ. 42(2), 521-532.

Abdel-Salam, A.M. and Rehman, M.M. (2008) Diversity of begomoviruses in Egypt (Unpublished).

Abhary, M.K., Anfoka, G.H., Nakhla, M.K. and Maxwell, D.P. (2006) Posttranscriptional gene silencing in controlling viruses of the Tomato Yellow Leaf Curl Virus complex. Arch. Virol. 151 (12), 2349-2363.

Abouzid, A.M. , Freitas-Astua, J., Purcifull, D. E., Polston, J. E., Beckham, K. A., Crawford, W.E., Petersen, B., Peyser, M.A., Patte, C. and Hiebert, E. (2002) Serological studies using polyclonal antisera prepared against the viral coat protein of four begomoviruses expressed in Escherichia coli. Plant Disease, 86(10), 1109-1114. 
Ajlan, A.M., Ghanem, G.A.M. and Abdul Salam, K.S. (2006) Tomato Yellow Leaf Curl Virus (TYLCV) in Saudi Arabia: Identification, partial characterization and virus-vector relationship. Arab J. Biotech. 10 (1), 179-192.

Allam, E.K., Abo El - Nasr, M. A., Othman B.A. and Thabeet, S.A. (1994) A new method for mechanical transmission of Tomato Yellow Leaf Curl Virus. Egyptian Phytopathol. Soc. 7, 91.

Aref, N.M., Abdallah, N.A., Allam, E.K. and Madkour, M.A. (1994) Use of polymerase chain reaction and radiolabelled specific probe to identify Tomato Yellow Leaf Curl Virus DNA from infected plants. Egyptian Phytopathol. Soc. 93, 109.

Argüello-Astorga, G., Guevara-González, R.G., Herrera-Estrella, L.R. and RiveraBustamante, R.F. (1994) Geminivirus replication origins have a group-specific organization of iterative elements: A model for replication. Virology, 203, 90-100.

Black, L.M., Brakke, K. and Vatter, A.E. (1963) Purification and electron microscopy of Tomato Spotted Wilt Virus. Virology, 20, 120-130.

Brown, J. K., Idris, A.M., Torres-Jerez, I., Banks, G.K. and Wyatt, S.D. (2001) The core region of the coat protein gene is highly useful for establishing the provisional. Identification of begomoviruses. Arch. Virol. 146, 1581-1598.

Clark, M.F. and Adams, N.E. (1977) Characterization of the microtitre plate method of enzyme - linked immunoassay (ELISA), for the detection of plant viruses. J. Gen. Virol. 37, 475-483.

Credi, R., Betti, L. and Canova, A. (1989) Association of a geminivirus with a severe disease of tomato in Sicily. Phytopath. Medit. 28, 223-226.

Crescenzi, A., Comes, S., Napoli, C., Fanigliulo, A., Pacella, R. and Accotto, G.P. (2004) Severe outbreaks of Tomato Yellow Leaf Curl Sardinia Virus in Calabria, outhern Italy. Communications in Agricultural and Applied Biological Sciences, 69(4), 575-580.

Czosnek, H. and Laterrot, H. (1997) A worldwide survey of Tomato Yellow Leaf Curl Viruses. Arch Virol .142, 1391-1406.

El-Dougdoug, K.A. and Aref, N.M. (1996) Biological and molecular diagnosis of three different symptoms of TYLC-disease in open field. Ann. Agric. Sci. Cairo, 41 (1), 173-185.

Fauquet, C., Sawyer, M., Idris, S. and Brown, J.K. (2005) Sequence analysis and classification of apparent recombinant begomoviruses infecting tomato in the Nile and Mediterranean Basins. Phytopathology, 95, 549-555.

Egypt. J.Microbiol. 45 (2010) 
Fazeli, R., Heydarnejad, J., Massumi, H., Shaabanian, M. and Varsani, A. (2009) Genetic diversity and distribution of tomato-infecting begomoviruses in Iran. Virus Genes. 38 (2), 311-9.

Gafni, Y. (2003) Tomato Yellow Leaf Curl Virus, the intracellular dynamics of a plant DNA virus. Molecular Plant Pathology, 4(1), 9-15.

Ghanem, M., Morin, S. and Czosnek, H. (2001) Rate of Tomato Yellow Leaf Curl Virus pathway at its vector, the whitefly Bemisia tabaci. Phytopathology, 91, 188- 196.

Gibbs, A. and Mackenzie, A.A (1997) primer pair for amplifying part of the genome of all potyvirids by RT-PCR. J. of Virological Methods, 63, 9-16.

Gilbertson, R.L., Haidayat, S.H., Martinez, R.T., Leong, S.A., Faria, J.C., Morrales F. and Maxwell, D.P. (1991) Differentiation of bean-infecting geminiviruses by nucleic acid hybridization probes and aspects of bean golden mosaic in Brazil. Plant Dis. 75, 336-342.

Harrison, B. D. and Robinson, D. J. (1999) Natural genomic and antigenic variation in whitefly-transmitted geminiviruses (begomoviruses). Annual Review of Phytopathology, 37, 369-398

Ioannou, N. (1995) Yellow leaf curl and other disease of tomato in Cyprus. Plant Pathol. 34, 428-434.

Lazarowitz, S. and Geminiviruses, G. (1992) Genome structure and gene function. Critical Reviews in Plant Sciences, 11, 327-349.

Loebenstein, G., Akad, F., Filatov, V., Sadvakasova, G., Manadilova, A., Bakelman, H., Teverovsky, E., Lachmann, O. and Davis, A. (1997) Improved detection of Potato leaf roll Luteovirus in leaves and tubers with a digoxigenin-labeled cRNA probe. Plant Disease, 81, 489-491.

Moustafa, S. E. (1991)Tomato cultivation and breeding programme for Tomato Yellow Leaf Curl Virus. pp. 6-8 in: resistance of the tomato to TYLCV, Proceedings for the seminar of EEC contract DGXII-TS2-A-055 F (CD) partners. H. Latterrot, and C. Trousse, (Ed). INRA-Station de' Amelioration des plantes Maraicheres, Montfavet-Avignon, France.

Noordam, D. (1973) "Identification of Plant Viruses. Methods and Experiments". Center of Agriculture Publishing and Demonstration (Pudoc), Wageningen.

Polston, J.E., Rosebrock, T.R, Sherwood, T., Creswell, T. and Shoemaker, P.J. (2002) Appearance of Tomato Yellow Leaf Curl Virus in North Carolina. Plant Disease, 86 (1), 73 . 
Rojas, M. R. (1992) Detection and characterization of whitefly-transmitted geminiviruses by the use of polymerase chain reaction. M. Sc. Thesis. Departement of Plant Pathology. University of Wisconsin-Madison at Madison. 92 pp.

Sider, M.M.F., Franco, A. D., Vovlas, C. and Gallitelli, D. (2001) First report of Tomato Yellow Leaf Curl Virus in Apulia (Southern Italy). J. of Plant Pathol. 83 (2), 148.

Sinisterra, X., Patte, C.P., Siewnath, S. and Polston, J. E. (2000) Identification of Tomato Yellow Leaf Curl Virus-Is in the Bahamas. Plant Disease, 84 (5), 592.

Varma, A. and Malathi, V.G. (2003) Emerging geminivirus problems: A serious threat to crop production. Annals of Applied Biology, 142, 145-164.

Zambrano, K., Carballo, O., Geraud, F., Chirinos, D., Fernandez, C. and Marys, E. (2007) First report of Tomato Yellow Leaf Curl Virus in Venezuela. Plant Disease, 91(6), 768.

( Received 8 / 8 / 2010 ;

accepted $29 / 11 / 2010$ )

Egypt. J.Microbiol. 45 (2010) 


\section{الكثف والتعرف على فيروس تجعد واصفرار أوراق الطماطم باستخدام تقنية PCR}

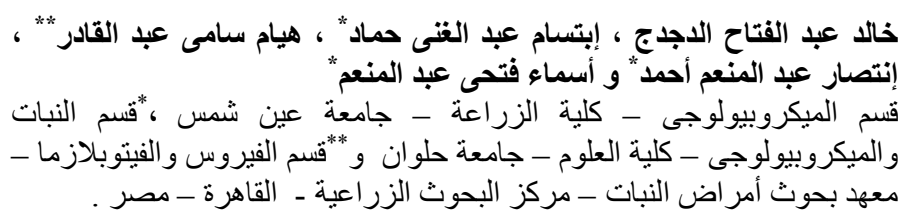

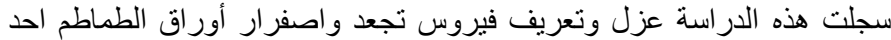

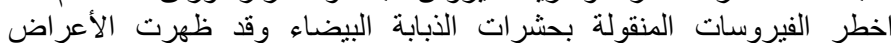

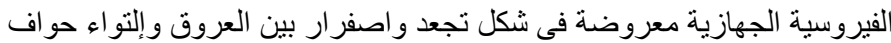

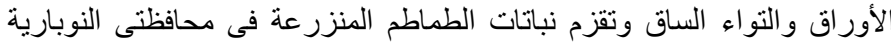

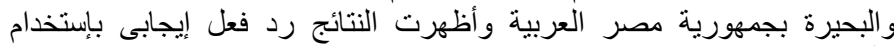

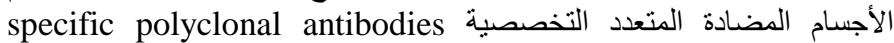
للكثف عن الفيروس بالطريقة السيرولوجية DAS-ELISA وقد أثنارت الدئية الدراسة

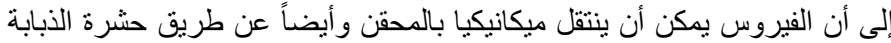

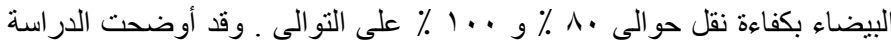

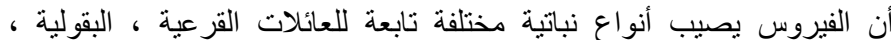

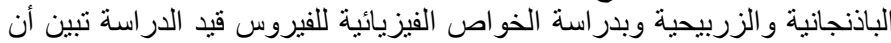

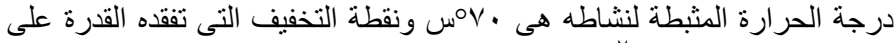

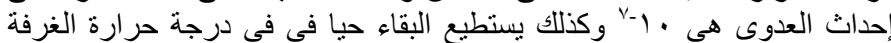

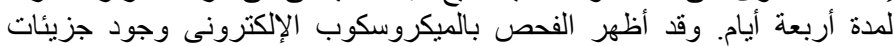

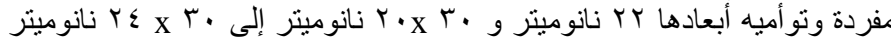

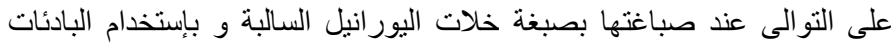

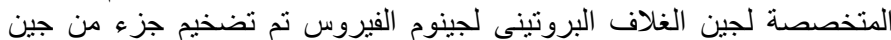

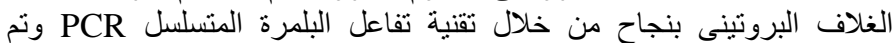

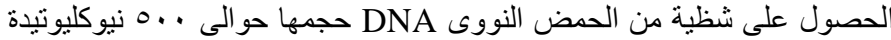

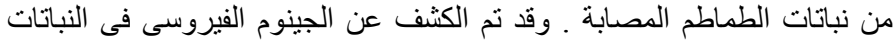
المصابة بواسطة مجس متخصص من DNA بإستخدام طريقة التهجين النقطى Do blot hybridization

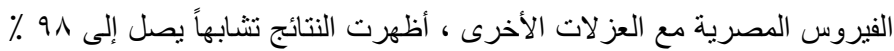

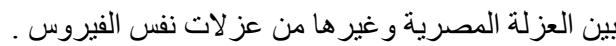

